PROBLEMS

OF EDUCATION

IN THE $21^{\text {st }}$ CENTURY

Volume 62, 2014

74

\title{
MANAGING TEACHER PERFORMANCE AND ITS APPRAISAL: DILEMMAS OF SCHOOL PRINCIPALS
}

\author{
Jabulani E. Mpungose \\ South African National Biodiversity Institute, South Africa \\ E-mail: j.mpungose@sanbi.org.za \\ Thengani H. Ngwenya \\ Durban University of Technology, South Africa \\ E-mail: ngwenyat@dut.ac.za
}

\begin{abstract}
Utilizing a grounded theory approach to understand the issues surrounding teachers' performance appraisal, the researchers investigate the principals'understanding of the Integrated Quality Management System (IQMS) and also explore the problems and flaws in its implementation. A purposive sampling procedure was used to select six school principals from three education regions in KwaZulu-Natal for the study. The results of the data analysis indicate that the implementation of the IQMS at schools has not been smooth. There has been a lot of hostility, negativity and resistance from the teachers that were appraised. The challenges that the principals were faced with, emanated from the lack of coordination, lack of trust, lack of clarity of roles and poor training. It is recommended that trust and better understanding be built between principals and teachers through information-sharing seminars and workshops, and regular feedback from the education officials.

Key words: appraisal, implementation, IQMS, peer group, performance measurement, professional development, salary increase.
\end{abstract}

\section{Introduction}

Studies on performance appraisal (Bell, 1988; Timperley and Robinson, 1997; De Clercq, 2008) show that the implementation of education policies by school principals is poor and slow, which eventually leads to poor performance by both teachers and principals. One of the reasons for such poor and slow implementation is the non-consideration, during policy formulation, of the local or contextual conditions which such policies are meant to influence. Successful implementation of policy (Whitty, 1992) is dependent on the development of such policy with the knowledge of local constraints that will impact on the implementation and therefore result in good performance. Bell (1988) and Khumalo (2008) maintain that the most appropriate and effective performance appraisal system is that which ensures the democratic involvement and participation of relevant individuals in the development process, and is derived from and rooted in the circumstances of each school.

In both the global and national contexts the performance appraisal of teachers, the majority of whom are public servants, is a contested issue. On the one hand, are those policy advisors who see it as a way of increasing efficiency and productivity and therefore believe that private sector models of performance management should be applied in public services like education. On the other hand, are theorists and intellectual activists who are vehemently 
opposed to what they regard as the implementation of neoliberal and managerial policies in the public service (Thrupp \& Wilmott, 2003). As Pollitt (1990) has convincingly shown in his study of the British and American public management contexts, the debates around performance management in the public service are both ideological and pragmatic. While not ignoring the ideological underpinnings of performance management in South African schools this paper focusses primarily on the pragmatic considerations that impede effective implementation.

This study investigates the implementation of the Integrated Quality Management System (IQMS) in South African primary and secondary public schools. The argument in this study is that, despite the fact that the new appraisal system was designed to bring quality teaching and learning, its implementation has failed or has never been completed in many public schools since its introduction in 2005, because there has been no proper consultation during its formulation and furthermore no proper training of the teachers and principals before the implementation. The implementation of the IQMS is the overall responsibility of the principal who leads the school management team in the process. The appraisal system requires school principals to "balance reasonable external demands for organizational accountability with the understanding that effective management of people in the school is the key to effective individual and team performance" (Middlewood, 2001, p.192). There is, however, always tension in maintaining a balance between organizational needs and individual needs in different organizations. Middlewood and Cardno (2001, p.11) argue that "the fundamental dilemma for leaders, which is the need to be concerned about meeting the goals of the organization and concern for maintaining positive collegial relationships, is exacerbated in the context of managing staff performance and its appraisal. It is this dilemma that creates the greatest challenge for those who need to manage the appraisal of professional colleagues".

The main rationale for introducing the IQMS was to integrate quality management and continuous professional development in South African public schools. The policy outlines recognisably developmental orientation while simultaneously proposing a system of measuring and rewarding good or excellent performance. Furthermore, the IQMS is used to help managers in timely predictions and taking actions promptly to improve working conditions and programmes. The policy also makes a deliberate link between teacher professional development and whole school development in a context where the former is subsumed under the latter. It's implementation results in good decision-making and accountability among the employees, and good human relations that contribute to school development. In terms of the standard conceptual models used in both public and private organisations it could be argued that the IQMS falls under the Total Quality Management model as it is essentially developmental in orientation.

\section{Purpose of the Study}

The purpose of this study is to examine the developmental appraisal and performance management and explore which appraisal strategy contributes to better teacher performance and better learner experiences and achievements. The purpose is to further locate debates relating to performance management within the context of international studies that promote teacher professional development and teacher professional growth as aspects of teacher performance appraisal that are collegial in nature, in which teachers assume responsibility for their own learning and professional growth (Beerens, 2000; Blase \& Blase, 1998, 1999). These studies tend to be critical of aspects of teacher performance appraisal that is conservative and hierarchical in nature because it involves controlled teacher supervision and represents a minimum commitment to teacher growth and development (Sergiovanni and Starratt, 1998, p. 289).

This study also explores the problems and flaws in the implementation of the IQMS and 
Jabulani E. MPUNGOSE, Thengani H. NGWENYA. Managing Teacher Performance and its Appraisal: Dilemmas of School Principals

PROBLEMS

OF EDUCATION

IN THE $21^{\text {st }}$ CENTURY

Volume 62, 2014

how the principals are dealing with the challenges and responsibilities of managing the new rigorous self-evaluation of schools. In order to achieve the objectives of the study, the research that was conducted seeks to understand the principals' knowledge of the IQMS, whether and how it has been implemented, and what changes have been observed in teaching and learning. It further seeks to find out if the training that they received is helping them to manage the appraisal process properly.

\section{The Teacher Appraisal System in South Africa}

The abolishing of the apartheid system of appraisal in the late 1980s, which was largely bureaucratic, top-down and authoritarian gave birth to the Integrated Quality Management System (IQMS) in 2003 when the Collective Agreement 8 was signed in the Education Labour Relations Council (ELRC). From the late 1980s up to the signing of the Collective Agreement 8 , there was no appraisal system especially in Black South African schools. On the $20^{\text {th }}$ June 2006 the Department of Education, for the first time, presented a report on the implementation of the IQMS to the Parliamentary Portfolio Committee on Education.

The IQMS was introduced as a framework for educational change which nurtures professional growth towards common goals and supports a learning community in which teachers are encouraged to improve and share insights in the profession. The IQMS introduced a new approach to teacher appraisal where teachers know what is required of them, are updated of their progress in the process and are supported to achieve all expectations (Bisschof and Mathye, 2009). Middlewood (2001, p.192) refers to these as "self-review, negotiation, reflection and feedback".

The reason for the development and implementation of the IQMS was that the results in learner achievement, especially in schools with predominantly African students, were unsatisfactory and that schools and education managers were no longer responding to the heightened expectations of parents and society (Portfolio Committee Report, 2006). The performance-based teacher evaluation system was therefore critical to improving teaching and learning in schools.

One of the key issues in the report was the challenge regarding the implementation of the IQMS. It was evident that the Department of Education was faced with more challenges in schools than successes. Among the challenges that were mentioned were:

- inadequate leadership and lack of quality resources,

- $\quad$ minimum support and commitment by the Department,

- lack of strong co-ordination and buy-in from the teachers and unions.

Two interrelated but fairly distinct aspects that co-exist within the IQMS were emphasised during the implementation of the framework. These were the Development Appraisal System (DAS) which looked at the personal professional growth and development of the teachers, and the Performance Measurement System (PM) which evaluated individual teachers for salary progression, grade, appointment affirmation and other rewards. At a practical level there was, however, no clear line of distinction between the two elements as they were implemented simultaneously.

The professional development strategy of DAS relates to personal professional growth of teachers which involves identifying strengths and weaknesses, acquiring and strengthening of new professional skills and abilities, and improving performance. It also provides an opportunity for discussion between teachers and supervisors during the appraisal process. The following areas of professional development can be identified:

- $\quad$ improving subject matter knowledge, which includes in-service training, reading, research, advanced study, and more;

- $\quad$ improving skills, which includes training on presentations or public speaking 
Bell $(1988$, p.16) argues that the emphasis in the dialogue or career review between the teacher and the more experienced colleague should be on planning the teacher's professional development, evolving improved or more appropriate teaching skills and on supporting the teacher rather than placing him or her in a competitive situation for promotion. The question is, however, how possible is this in a process whose results are expected to create promotion opportunities and salary improvement?

It is argued that (Bell, 1988; Draper, 2000; Middlewood, 2001) both school and teacher would benefit from regular periods of discussion and evaluation of the teachers about their current work and possible in-service training needs. This would require the agreement of the teachers to a regular staff review, once in a term or once in a semester. Such review would be unrelated to remuneration and promotion since its aim would be to constantly identify areas in which teachers need to be developed and provide professional enhancement and support for teachers.

De Clercq (2008) suggests that after the career reviews and evaluation of teachers, different kinds of in-service activities should be prepared and offered according to the various needs and work demands of the teachers. This should include on-site workshops, coaching by mentors or facilitators and generic lectures which should encourage teachers to share and reflect on their own practices with colleagues working in the similar contexts. At the end, teachers should be able to reflect on what they have learnt from their mentors and from each other, and use that to improve their pedagogical delivery and learn new practices.

Although the developmental appraisal process is meant to be transparent and supportive, school-based teachers to whom it has been advocated experience problems in trying to overcome negative influences that come up in their teaching. It has been argued that teacher appraisal processes lack trust, fairness, collegiality and commitment from the management (Timperley \& Robinson, 1977).

The performance measurement strategy relates to the evaluation of individual teacher performance of one's tasks or activities as required by the curriculum or job description for the purpose of promotion or pay progression. The emphasis in this strategy is on accountability or "professional monitoring" (de Clercq, 2008), where professional teachers are evaluating their colleagues' work. The appraised teachers are required to give an account of their attempts to meet their responsibilities and are scored accordingly. In this case the appraisal is based on the appraisal criteria and documented expectations set out by the Department of Basic Education, which the teachers have to meet when they are evaluated on the curriculum knowledge and delivery. According to Middlewood and Cardno (2001, p.11) such situation will lead to the "appraisal process being honed down to become just a mechanism for check-listing that minimum criteria have been met so that staff can be allocated a performance pay bonus or move to the next level on the pay scale".

Bell (1988) believes that in order for appraisal to be part of a set of strategies by which teachers are to be held accountable, it should provide a context for career and professional development where specific outcomes of a developmental nature can be identified. Teachers are expected to commit to the agreed improvement strategies in areas identified during the appraisal process. Sometimes teachers are not moved to the next salary level, even after attending inservice training or workshops. This has resulted in teachers insisting on pay bonuses rather than salary progression. It is, however, argued that relating performance to pay will lead to teacher 
Jabulani E. MPUNGOSE, Thengani H. NGWENYA. Managing Teacher Performance and its Appraisal: Dilemmas of School Principals

PROBLEMS

OF EDUCATION

IN THE $21^{\text {st }}$ CENTURY Volume 62,2014

appraisal losing its credibility of career development (Bell, 1988; Bassey, 1999; Middlewood, 2001).

Based on the appraisal issues mentioned above, the implementation as a responsibility of the principals has been hindered or delayed in many public schools. Bisschoff and Mathye (2009) and Hlongwane (2009), outlined the following shortcomings in the appraisal process:

- $\quad$ negative reaction from teachers and unions because of the poor cascading of information,

- $\quad$ poor or ineffective training of school-based teachers. Training sessions too short and some important aspects omitted or not clearly explained,

- $\quad$ absence of coordination and lack of clarity on the roles of those who are engaged in the process, and

- $\quad$ lack of trust and authority among all the appraisal teams. They did not feel in control of the process.

\section{Research Methodology}

This study utilizes the qualitative, interpretive research approach. Glaser and Strauss (1970) maintain that qualitative research is often the most adequate and efficient research perspective for dealing with inherently complex social issues and for obtaining the type of information required for contending with all difficulties of various research situations. According to Dey (1993, p.38) "Qualitative research often seeks to illuminate the ways individuals interact to sustain or change social situations". The qualitative research approach was useful in this study because it provided direct, first-hand and more contextual information about the principals' knowledge of, thoughts, experiences and views about the process of teacher performance appraisal (Mpungose, 2010). The qualitative research approach also allowed flexibility in the research process whereby we could change in the nature of my intervention in response to the changing nature of the context and circumstances.

\section{Sample}

In this study, a purposive or judgemental sampling procedure was used. The procedure is said to be judgemental because, owing to the experience of one of the authors as a former school principal, he used his own judgement about which respondents to choose and had picked only those who best meet the purpose of the study (Bailey, 1987). A total of six school principals were selected using this procedure from three education districts belonging to three education regions, each with more than 200 public schools. The reason for selecting six school principals was that the researchers wanted to have a manageable sample of informants as each principal was visited twice in order to follow up on some data. Two principals were selected from each region, each principal managing twenty or more teachers. The six principals were selected from rural, township and suburban schools. The reason for this was that different situations in terms of enrolment, resources, staffing, infrastructure, politics, parents, teacher qualifications, etc. exist within these schools, yet they are all public schools controlled by the South African Schools Act No. 48 of 1996 (SASA). The selection of the above sample would provide us with the kind of data that display the abilities of the principals to handle the unique circumstances under which they work.

\section{Data Collection}

Dey (1993) describes data collection as an interactive process through which the researcher struggles to elicit meaningful interpretation of social action. In order to gain a 
detailed picture of the principals' knowledge and perceptions of the IQMS and how they were implementing it, the researchers used in-depth, semi-structured interviews. A semi-structured interview lies somewhere between the structured and unstructured interviews because of its degree of imposed structure and open-ended questions. The semi-structured interviews were used to help us think ahead of difficulties that might arise and therefore plan on how to handle them. The principals' responses were captured by means of a tape recorder after obtaining permission in advance from each of them. The use of a tape recorder made it possible and easy for us to capture a full and accurate account of the interview.

During the interviews, the principals were treated with respect and their expert knowledge of the area of study was acknowledged. An interview guide with two sections focusing on the knowledge and implementation of the appraisal system, and the management of teacher performance respectively was used. The interview guide was used as a probe to clear up vague responses or to ask for elaboration of incomplete answers, but at the same time allowing the individual perspectives and experiences to emerge. It guided the principals to follow a particular structure or frame and not to tell what they thought we wanted to hear. The questions in the interview guide were asked in such a way that the same information was obtained from the selected principals. Among the questions that were asked were feeling questions that elicited the emotional responses of the principals to their experiences and thoughts, and knowledge questions which gave the factual information that the principals had or things that they knew.

\section{Data Analysis}

The analysis of data in this study was based on a grounded theory approach which allowed the researchers to go by feel and intuition in order to produce common themes and patterns from the data which was used as a basis for interpretation (Easternby-Smith, Thorpe and Lowe, 1994). Bitsch (2005, p.77) defines grounded theory as "a methodology of developing inductive theories that are grounded in systematically gathered and analysed data". The grounded theory approach, however, did not only take effect in the analysis of the data but was used from the time when we decided on the research problem or purpose of the study, to the framing of the research question, and the collection and coding of data. The use of the grounded theory approach provided us with insight, the ability to give meaning to data, the capacity to understand, and the capacity to separate the pertinent from that which is not (Strauss \& Corbin, 1990). It also helped us to develop a conceptual understanding of the selected school principals' perspectives and outlooks on issues surrounding teachers' performance appraisal.

While searching for recurrent patterns, themes and structuring devices in the responses of the principals during the interviews, we were required to make a series of deliberate, critical choices about the meanings and values of the data that were collected. These themes were used in the analysis of the data and also in the reporting of the findings of the study. Furthermore, the themes were linked into a more comprehensive model that resulted from the findings. Four major themes emerged from the record of the interviews:

- Knowledge and understanding of the appraisal system.

- Challenges in the implementation of the appraisal system

- Improvement in teaching and learning.

- Managing teacher performance appraisal.

The qualitative data analysis process casted us in a role of discoverers, who, from the responses of the selected principals, unearth problems, identify indicators, formulate hypotheses, develop conceptualizations and examine their adequacy (Dey, 1993). The rich and authentic data which resulted from the interviews are presented as direct extracts under the above themes. 
Jabulani E. MPUNGOSE, Thengani H. NGWENYA. Managing Teacher Performance and its Appraisal: Dilemmas of School Principals

PROBLEMS

OF EDUCATION

IN THE $21^{\text {st }}$ CENTURY

Volume 62,2014

\section{Results of Research}

Knowledge and understanding of the appraisal system

The appraisal system requires the principals, heads of departments and teachers to have knowledge, understanding and capacity of maintaining high evaluation standards. The research shows that many schools in South Africa do not have experienced effective internal appraisers whose experience could be necessary for quality professional development and teaching:

Principals were given one day crash courses which I think were not enough for delivering a process like this. Of course, it was helpful in a way, but you know that some people can catch up fast and others cannot and we end up with challenges. Those of us who are studying at universities have a better understanding of the process and can help teachers to have a better understanding of the process (Principal B).

It became evident in the responses that there were different perceptions of the appraisal system among the principals and their staff. At some schools there was confusion and disagreement around the structures, like the School Development Team (SDT) and Development Support Groups that should be formed:

The appraisal system is pretty much the same as other processes that are a waste of time because people were not properly trained. The reason for this was that the trainers from the department who were training principals and heads of departments did not have good knowledge themselves. The school management team will pass this incomplete and inferior knowledge to the teachers at school. The leaders of the teacher unions would also bring their own understanding and would like the structuring of the appraisal committees to favour the teachers. Teachers choose their friends who do not specialise in the subject they are scoring to be in their peer groups, how can that be? (Principal A).

\section{Challenges in the implementation}

It was evident that teachers' attitudes towards staff appraisal are determined, in part, by the meanings which they attach to it and by their interpretations of the meanings attached to appraisal by other significant people. The implementation of the appraisal system has not been an easy task for the principals and their school management teams who would prefer it to be done regularly so that teachers could get used to it and for it to be effective:

The fact that the appraisal system is done once in a year for a few hours does not give a true picture of the teacher's abilities. It is a matter of filling in forms then it's quickly done. I think it should become a culture of the school to do it from the beginning of the year until perhaps the end of the third quarter, so that it's a process to develop themselves rather than increase their salaries (Principal B).

They have to follow procedures with set times and cannot bring in additional information, methods or suggestions to contribute to even better staff performance:

We are spending more time looking for delivery in the classroom, which will ensure a continuous standard of work as opposed to looking at a teacher in a period of once a year and they prepare for that one particular lesson that I will be listening to and to a certain extent we are restricted to the given amount of time (Principal E). 
Jabulani E. MPUNGOSE, Thengani H. NGWENYA. Managing Teacher Performance and its Appraisal: Dilemmas of School Principals

$\mid$\begin{tabular}{l} 
PROBLEMS \\
OF EDUCATION \\
IN THE 21 $1^{\text {st }}$ CENTURY \\
Volume 62, 2014 \\
\hline 81
\end{tabular}

The challenges emanated from the difficult power relationships or different opinions between the appraisers and appraisees, lack of trust, unprofessional behaviour and lack of commitment. At the end, there is no enthusiasm and principals 'do it because they have to':

The appraisal system is becoming one that we are simply implementing as opposed to doing it for the sake of development and it is common from the reports received from many schools to endorse the procedure for the sake of process. There is no real development process on the ground. We don't have the expertise coming in saying Mr Principal, we have highlighted a particular area in your school and would like to come in and make changes (Principal D).

What also came up was staff striving to meet a certain minimum criteria so that they can be allocated a performance pay bonus or moved to the next level of the pay scale:

There are challenges when it comes to scoring because no one wants to be scored low. They all want to get high scores, I don't know why, but I think it is about the 1\% increment that the department put as an incentive. (Principal C).

There was a concern that a direct link between appraisal and promotion would be to the detriment of good teaching and that teachers were losing sight of the fundamental benefit of appraisal:

People only perform at their utmost best during the appraisal, but during the year their work is poor. They score themselves very high because they were promised a 1\% salary increase if they perform well (Principal F).

\section{Improvement in teaching and learning}

According to the principals, the purpose of the appraisal system is to help to improve the quality of teachers and to ensure that they are adequately trained to teach in the classroom and they are accountable to some authority in the school:

The appraisal does not give us enough room for further developments. There is no real improvement in teachers' performance. In certain task teams in the district, the development teams have not met their targets in making sure that the teachers are adequately trained after we submit to them. There has been no feedback or tangible, physical thing to say that they are meeting with the requirements and the needs of the school's development programmes in the area. They leave it largely to the school itself to deal with the matter of developing the teachers, which becomes cumbersome (Principal E).

What was most fundamental to them was giving and receiving feedback which builds a platform for launching possibilities for development. This, however, did not happen and they therefore felt that it was a cumbersome and fruitless exercise which does not bring any benefit:

We work very hard conducting the performance evaluation and at the end we send the results to the department to act on the recommendations. We don't get any feedback from the department; then it becomes a fruitless exercise because the teachers are not developed. Sometimes a teacher needs to refresh in content or might have a problem in handling his or her own personal life which might negatively impact on his or her performance and these can only be handled by units in the department. What is the purpose of completing the process and sending our records yearly to the department if they don't take the necessary actions? (Principal B). 
Jabulani E. MPUNGOSE, Thengani H. NGWENYA. Managing Teacher Performance and its Appraisal: Dilemmas of School Principals

PROBLEMS

OF EDUCATION

IN THE $21^{\text {st }}$ CENTURY

Volume 62,2014

Some of the schools that the researchers visited are well-performing functioning schools that are better equipped to manage and mediate the appraisal expectations in a productive way. The principals of these schools were positive about the results of the appraisal system:

The appraisal system has helped us a lot because it's not like in the previous times where you will be scared of someone coming in your class to observe you. Now the teachers are free, confident and motivated. The mere fact that they are taking charge of their own development; the mere fact that they can do self-assessment and that they are able to find their faults and strengths is proof that they are growing and becoming accountable (Principal C).

\section{Managing teacher performance appraisal}

Managing staff appraisal means seeing to it that the process runs smoothly and does not damage relationships between the principal and staff. In order to achieve this, the principal needs to first understand his or her role in the process and thereafter develop trust, commitment and understanding among the staff:

$\mathrm{My}$ role as the principal is to make sure that I know what is expected of me and monitor the formation of all the appraisal committees, verify the scores and lead the moderation of the results (Principal D).

My role is to see that the IQMS is followed. I do not sit in the appraisal panel, but I do go to the classroom to observe if they are following the procedure. My deputy has been tasked with sitting in the appraisal process and she reports to me. I'm only fully involved in the moderation of results (Principal C).

Over and above knowing what is required to be done, the principal should ensure that the teachers receive guidance, support and challenge when required; and also receive feedback about progress and achievement:

My role has become one of an observer. I ensure that the committee, which is the SDT, is in place and a chairperson who takes control of the process is elected. The SDT team normally takes control of the entire process and reports to me in terms of scope and they will present to me their findings and as the principal I will look at the results because I have my own assessment in terms of planning and goals for the year. If I find that the scores are way too low, I make a request to go back to the team and adjust; if not reduce the scores if they are unusually too high or look at a more reasonable performance measure in terms of scores (Principal E).

\section{Discussion}

The analysis of the interview responses revealed that the challenges that the principals came across during the implementation of the appraisal system emanated from the lack of coordination, trust by-in from the teachers, clarity of roles and poor training. Rasheed, Aslam, Yousaf and Noor (2011) maintain that teachers perceive appraisal system as an effective management tool when they are satisfied with their principal and have trust in him or her. The analysis also revealed that there is an uneasy co-existence of two teacher appraisal strategies within the IQMS. Hannay, Telford and Seller (2003) however, believe that the two strategies should be congruent and consistent in order for the process to be authentic and focused on professional growth, A question that comes up is, "to what extent does this co-existence of these strategies help in identifying teachers' strengths and weaknesses with the aim of improving their performance and the learners' achievements? Wadesango, Nduna and Kurebwa (2013) maintain that performance management can be used to promote both professional development and individual advancement in terms of salary and promotion. 
In the context of teacher appraisal some scholars subscribe to the view that performance management should be totally developmental and should not lead to a judgment that could have financial implications (Beerens, 2000). The linking of the performance measurement strategy to pay bonuses and/or promotion exacerbates the situation because its outcome is seen as not related to career development and can also undermine attempts to provide honest feedback (Wadesango et al, 2013). Too much focus is on getting high scores in order to qualify for the 1\% salary increase. Messah and Kamencu (2011) maintain that performance bonuses are a better alternative for rewarding performance because they are once-off payments that are not institutionalized. Bonuses are motivational because they are based on performance over a specified time.

The preferred approach as reflected in the findings of this study is that of a system continuous professional development based on the principle of collegiality and trust in which roles, responsibilities and expectations of various stakeholders are made explicit to all concerned. Such a system would neither be punitive nor judgmental, but would be truly developmental and would promote trust between teachers and principals. The debate on the tension between accountability and professional development in the public sector performance management systems is well documented in the relevant literature (Beardell, 1995, Power, 1997, Bartlett, 2000, Beerens, 2000; Guskey 2000). The ideological underpinnings of a performance management system borrowed from the private sector in accordance with what is known as the New Public Management (NPM) have been critically explored in various publications (Thrupp \& Wimott, 1992 \& 2003; Ferlie et al, 1996, Hood, 1991; Power, 1997; Pollitt, 1990). As mentioned in the introductory section, the discussion in this study focuses on the practical aspect of policy implementation and not on the conceptual and theoretical underpinnings of I QMS.

In their responses, the principals made it clear that the training that they were given was not enough and inferior. It also came out that the knowledge that the teachers obtained from unions clashed with that of the principals. It was clear that the appraisal leaders and managers do not have adequate knowledge and experience. A question that remains is whether the appraisal system can develop the capacity to produce the knowledgeable, well trained professional appraisers who have access to sufficient data information to interpret effectively the appraisal instrument, to reflect adequately on educators' practices and areas of development and compile meaningful personal growth plans (de Clercq, 2008)? Unless the training is improved and the roles are clarified, the answer is no. Messah and Kamencu (2011) agree when they say that a good training programme will enhance the results of a performance appraisal system of an organization. They believe that factors such as frequent training, good training methods, relevant knowledge, enough time and knowledgeable trainers will influence the effectiveness of the performance appraisal system.

\section{Conclusions}

Out of a number of concerns that were expressed by the principals was the negative reaction to the appraisal system by the teachers and the unions, which made the implementation difficult. The researchers' recommendation would be that any staff appraisal process should be introduced into a school carefully and effectively in order to overcome the suspicions and concerns, and to bring back trust between the staff and the school management teams. There should also be seminars and workshops to share new information and clarify roles of the school management and school development teams. The education officials themselves should give regular and constant feedback after a completion of each Development Appraisal process.

The combination of the Development Appraisal and the Performance Measurement Strategies in the IQMS was a serious concern. It further exacerbates the already difficult power 
Jabulani E. MPUNGOSE, Thengani H. NGWENYA. Managing Teacher Performance and its Appraisal: Dilemmas of School Principals

PROBLEMS

OF EDUCATION

IN THE $21^{\text {st }}$ CENTURY

Volume 62, 2014

relationship between appraisees, school-based appraisers and district appraisers. These parties

have different interests and agendas in this evaluation, thus threatening rigorous, reliable and valid evaluation. There is a need for a regular implementation of the Development Appraisal Strategy and a separate once-a-year implementation of a Performance Measurement process for progression and/or bonuses. This would give the local education authorities reliable, comprehensive and up-to-date information to facilitate effective professional support and development.

\section{References}

Alvesson, M., \& Wilmott, H. (Eds.). (1992). Critical management studies. London: Sage.

Bartlett, S. (2000). The development of teacher appraisal: A recent history. British Journal of Educational Studies, 48 (1), 24-37.

Bazeley, P. (2009). Analysing qualitative data: More than 'identifying themes'. Malaysian Journal of Qualitative Research, 2, 6-22.

Beardell, J. (1995). Teacher appraisal and professional accountability in South African education. Perspectives in Education, 16 (2), 365-372.

Beerens, D. (2000). Evaluating teachers for professional growth: Creating a culture of motivation and learning. Thousand Oaks: Corwin Press.

Bell, L. (1988). Appraising teachers in schools: A practical guide. London: Routledge.

Bisschoff, T., \& Mathye, A. (2009). The advocacy of an appraisal system for teachers: A case study. South African Journal of Education, 29, 393-404.

Bitsch, V. (2005). Qualitative research: A grounded theory example and evaluation criteria. Journal of Agriculture, 23 (1), 75-91.

Blasé, J., \& Blasé, J. (1998). Handbook of instructional leadership: How really good principals promote teaching and learning. Thousand Oaks: Corwin Press Inc.

Blasé, J., \& Blasé, J. (1999). Principals' instructional leadership and teacher development: Teacher perspectives. Educational Administration Quarterly, 35 (3), 349-378.

De Clercq, F. (2008). Teacher quality, appraisal and development: The flaws in the IQMS. Perspectives in Education, 26 (1), 7-18.

Dey, I. (1993). Qualitative data analysis: A user-friendly guide for social scientists. London: Routledge.

Easterby-Smith, M., Thorpe, R., \& Lowe, A. (1994). Analysing qualitative data. In N. Bennett, R. Glatter and R. Levačić (Eds.), Improving educational management through research and consultancy. London: Paul Chapman Publishing.

Ferlie, E., Ashburner, L., Fitzgerald, L., \& Pettigrew, A. (1996). The new public management in action. Oxford: Oxford University Press.

Glaser, B. G., \& Strauss, A. L. (1970). Discovery of substantive theory: A basic strategy underlying qualitative research. In W.J. Filstead (Ed.), Qualitative methodology: Firsthand involvement with the social world. Chicago: Markham Publishing Company.

Guskey, T. R. (2000). Evaluating professional development. Thousand Oaks: Corwin Press.

Hannay, L. M., Telford, C., \& Seller, W. (2003). Making the conceptual shift: Teacher performance appraisal as professional growth. Educational Action Research, 11 (1), 121 137.

Hlongwane, T. S. (2009). Empowering educator teams to implement the integrated quality management systems in secondary schools in the Kathorus Area. Unpublished DEd Thesis. Johannesburg: University of Johannesburg.

Hood, C. (1991). A public management for all seasons. Public Administration, 69, 3-9. 
Jabulani E. MPUNGOSE, Thengani H. NGWENYA. Managing Teacher Performance and its Appraisal: Dilemmas of School Principals

$\mid$\begin{tabular}{l} 
PROBLEMS \\
OF EDUCATION \\
IN THE 21 $21^{\text {st }}$ CENTURY \\
Volume 62,2014 \\
\hline 85
\end{tabular}

Messah, O. B., \& Kamencu, S. M. (2011). The Effect of performance appraisal systems on employees in Kenya Tea Development Agency: A survey of selected tea factories in Meru County-Kenya. Research Journal of Finance and Accounting, 2 (3), 16-31.

Middlewood, D., \& Cardno, C. (2001). The significance of teacher performance and its appraisal. In D. Middlewood and C. Cardno (Eds.), Managing teacher appraisal and performance: A comparative approach. London: Routledge/Falmer.

Mpungose, J. (2010). Constructing principals' professional identities through life stories: An exploration. South African Journal of Education, 30, 527-537.

Power, M. (1997). The audit society: Rituals of verification. Oxford: Oxford University Press.

Pollitt, P. (1990). Managerialism and the Public Services: The Anglo-American Experience. Oxford: Blackwell.

Ramsey, P., \& McLellan, J. (2006). Can performance appraisal work in schools? New Zealand: New Zealand Principals' Federation Magazine.

Rasheed, M. I., Aslam, H. D., Yousaf, S., \& Noor, A. (2011). A critical analysis of performance appraisal system for teachers in public sector universities of Pakistan: A case study of the Islamia University of Bahawalpur. African Journal of Business Management, 5 (9), 3735-3744.

Sergiovanni, T. J., \& Starratt, R. J. (1998). Supervision: A redefinition. Boston: McGraw Hill.

Strauss, A., \& Corbin, J. (1990). Basics of qualitative research: Grounded theory procedures and techniques. Newbury Park, CA: Sage Publications.

Taylor-Powell, E., \& Renner, M. (2003). Analyzing qualitative data. Wisconsin: University of Wisconsin-Extension.

Timperley, H. S., \& Robinson, V. M. J. (1997). The problem of policy implementation: The case of performance appraisal. School Leadership \& Management, 17 (3), 333-345.

Trupp, M., \& Willmott, R. (2003). Education management in managerialist times: Beyond the textual apologists. Philadelphia: Open University Press.

Turner, G., \& Clift, P. (1988). Studies in teacher appraisal. London: The Falmer Press.

Wadesango, N., Nduna, D., \& Kurebwa, M. (2013). An investigation into teachers' attitudes towards performance management in Zimbabwe. Anthropologist, 15 (2), 157-165.

Advised by Vincentas Lamanauskas, University of Siauliai, Lithuania

Received: July 21, 2014

Accepted: December 16, 2014

\begin{tabular}{|ll} 
Jabulani E. Mpungose & $\begin{array}{l}\text { Dr (PhD), Assistant Director, South African National Biodiversity Institute, P.O. } \\
\text { Box 21667, Pietermaritzburg, 3200, South Africa. } \\
\text { Email: J.Mpungose@sanbi.org.za } \\
\text { Web: www.sanbi.org.za }\end{array}$ \\
\hline Thengani H. Ngwenya & $\begin{array}{l}\text { Associate Professor, Centre for Excellence in Learning \& Teaching, Durban } \\
\text { University of Technology, P.O. Box 1334, Durban 4000, South Africa. } \\
\text { Email: ngwenyat@dut.ac.za } \\
\text { Website: http://www.dut.ac.za }\end{array}$
\end{tabular}

